\title{
Especialidades Médicas - Pediatria e Neonatologia
}

\author{
André Laranjeira Carvalho
}

\section{Dificuldades iniciais da carreira}

Posso citar três dificuldades que todo pediatra recém formado passará: a dificuldade no relacionamento com a família do paciente, a falta de experiência médica inerente a qualquer recém formado e a escolha de uma especialidade ou área de atuação dentro da pediatria.

A Pediatria é uma especialidade que cuida de uma fase da vida. Cuida desde o período neonatal até a adolescência. Nesse contexto um médico pediatra recém formado deve ter a habilidade de atender e cuidar de pacientes em diferentes momentos de vida, por exemplo, em um pronto socorro o pediatra atende um lactente e logo em seguida um adolescente, sendo obrigado a ter um raciocínio clínico totalmente diferente em cada situação. Esta é uma dificuldade que vai se dissipando conforme o pediatra fica mais experiente.

Além disso, os pediatras devem manter uma boa relação com a família do paciente para que o tratamento indicado seja eficaz. Em algumas situações nas quais os familiares não confiam no pediatra, pode haver conflitos e o mais prejudicado é o paciente. Por isso, o pediatra é um médico completo. Deve saber lidar com a família do paciente, explicando as doenças e as condutas médicas e trazendo a família para seu lado no cuidado do paciente, e deve também ter muito conhecimento médico para que o paciente seja atendido da melhor maneira.

Em relação ao mercado de trabalho não há dificuldade para arrumar empregos, mas pode haver dificuldades e dúvidas para escolher uma especialidade, pois a área de atuação da pediatria é ampla. O pediatra pode trabalhar em consultório particular, ambulatório geral e de especialidades (cardiopediatria, neuropediatria, onco, pneumo, reumato, cardio, etc), prontos socorros, enfermarias, UTI pediátrica e neonatal, salas de parto, berçários, alojamentos conjuntos, em escolas, unidades básicas de saúde e em muitas outras áreas relacionadas a pediatria. Até mesmo as áreas administrativas de um serviço médico de pediatria podem ser conduzidas por um pediatra devidamente preparado para assumir cargos administrativos, em que sua experiência médica ajuda na tomada de decisões. Nada impede que um pediatra se especialize em mais de uma área e a dúvida na escolha da especialização é um reflexo da formação generalista, porque mesmo sendo especialista ele ainda atuará com pediatria geral ao longo de sua carreira, sendo poucos aqueles que trabalham exclusivamente como especialitas.

Perfil dos casos abordados (leve, médio, grave, gravíssimo)

Cada área da Pediatria tem um perfil de paciente e dentro de cada perfil casos diversos. Poderia citar uma infinidade de casos e situações em cada perfil. Mas vou citar apenas exemplos que um pediatria geral e um neonatologista podem enfrentar na sua rotina.

Um exemplo de caso leve é o paciente que passa em consulta ambulatorial de puericultura. $\mathrm{O}$ paciente pode ou não ter uma doença, mas precisa 
de um seguimento pediátrico para acompanhar seu desenvolvimento, esclarecer dúvidas e orientar os familiares. Quando requisitado, nessas consultas, o pediatra também pode tratar doenças e solicitar exames. Pode-se citar um recém nascido que está em aleitamento materno e retorna na consulta para verificar o peso.

Um caso médio pode ser visto em um pronto socorro, por exemplo, um paciente com crise de asma leve ou moderada, que necessita de beta 2 agonista inalatório e corticoide sistêmico. Outro exemplo é um paciente recém nascido prematuro que nasceu com menos de $2 \mathrm{~kg}$ e está ganhando peso em um berçário. Esses pacientes normalmente estão internados em enfermarias, apartamentos ou berçários, não necessitando de cuidados intensivos.

Um exemplo de caso grave é uma criança com insuficiência cardíaca, por cardiopatia congênita, que descompensa por uma pneumonia, necessitando de monitorização hemodinâmica. Ou também um recém nascido prematuro que tem uma infecção bacteriana (sepse neonatal, pneumonia ou meningite) e necessita de antibioticoterapia endovenosa, podendo evoluir para choque séptico e uso de drogas vasoativas. Este é o perfil de paciente que interna em uma unidade de terapia intensiva (UTI).

Os casos gravíssimos são aqueles graves que podem evoluir mal. São os pacientes com imunodeficiência primária ou os oncológicos com choque séptico, que mesmo usando drogas vasoativas, antibioterapia de amplo espectro e até antifúngicos de última geração, continuam a piorar clinicamente, evoluindo para parada cardiorrespiratória. Mais um exemplo são os prematuros extremos que nascem com insuficiência respiratória, são intubados em sala de parto, recebem surfactante na UTI, permanecem em ventilação mecânica, mas o quadro respiratório continua a se deteriorar, necessitando de ventilação de alta frequência.

\section{Quando e como decidiu pela especialidade}

Comecei a pensar em Pediatria no terceiro ano quando tive propedêutica da criança e decidi no sexto ano quando passei em Neonatologia no Hospital Universitário. Gostei tanto que hoje faço Neonatologia.

Adoro a sensação de dever cumprido quando trato uma criança e vejo que ela respondeu ao tratamento. A criança reflete verdadeiramente o que ela sente, então quando está doente ela realmente fica triste e desanimada, mas quando ela melhora, fica alegre e logo ela estará brincando e sorrindo.

Outro motivo que me fez escolher a Pediatria foi a grande possibilidade de empregos, desde plantões em pronto socorros e UTI até atendimentos ambulatoriais e visitas em pacientes internados. Além disso existe ainda uma série de especialidades que podem completar a formação geral do pediatra: endocrinologia, cardiologia, nefrologia, neurologia, reumatologia, imunologia, infectologia, genética, gastroenterologia, pneumologia, neonatologia, terapia intensiva, nutrologia, oncologia, hematologia, dor e cuidados paliativos em pediatria, atenção primária à saúde da criança (UBS) e outras.

E dentro do Instituto da Criança do HCFMUSP você tem a oportunidade de ter aulas, discutir casos e condutas com os maiores pediatras do Brasil, que influenciaram várias escolas médicas e transformaram a Pediatria moderna. 